\title{
KECENDERUNGAN ANAK MENJADI PELAKU DAN KORBAN BULLYING DITINJAU DARI KUALITAS KELEKATAN DENGAN IBU YANG BEKERJA
}

\author{
Sri Wahyuni \& Yulita Kurniawaty Asra \\ Fakultas Psikologi UIN Suska Riau \\ Email:ziyadrafif@gmail.com
}

\begin{abstract}
Bullying has become a serious problem in schools and occurs in all countries. The purpose of this study is to see the tendency of children to be actors and victims of bullying in terms of quality of attachment with working mothers. The subjects were 336 students (175 male and 161 female) who have working mothers. The results showed that students who have a low quality of attachment with the mother who works has the tendency to be actors and victims of bullying than students who have a high attachment quality. Students in higher classes tend to bullying than students in lower grade, and boys were also higher tendency to bullying than girls. For mothers working hours, there was no difference in bullying behavior. While the tendency to be a victim, there is no difference based on class and gender. However, mothers who have longer working hours make children easily become victims of bullying.
\end{abstract}

Keywords: Attachmennt, victims of bullying, actors of bullying

\begin{abstract}
Abstrak: Perilaku bullying sudah menjadi masalah serius di sekolah dan terjadi di seluruh Negara. Tujuan penelitian ini adalah untuk melihat kecenderungan anak menjadi pelaku dan korban bullying ditinjau dari kualitas kelekatan dengan ibu yang bekerja.Subjek penelitian adalah 336 siswa (175 laki-laki dan 161 perempuan) yang memiliki ibu yang bekerja. Hasil penelitian menunjukkan bahwa siswa yang memiliki kualitas kelekatan yang rendah dengan ibunya yang bekerja memiliki kecenderungan menjadi pelaku dan korban bullying dibanding siswa yang memiliki kualitas kelekatan yang tinggi.Siswa yang kelasnya lebih tinggi cenderung melakukan bullying dibanding kelas lebih rendah, dan siswa laki-laki juga lebih tinggi kecenderungan melakukan bullying dibanding siswa perempuan. Untukjam kerja ibu, tidak ada perbedaan perilaku bullying-nya. Sedangkan kecenderungan menjadi korban, tidak terdapat perbedaan berdasarkan kelas dan jenis kelamin. Namun jam kerja ibu yang lebih lama menjadikan anak mudah menjadi korban bullying.
\end{abstract}

Kata Kunci: Kelekatan, Pelaku Bullying, Korban Bullying

\section{PENDAHULUAN}

Perilaku bullying ini sudah mulai menjadi perhatian di berbagai Negara semenjak tahun $1980-$ an $^{1}$, dan perilaku bullying ini terjadi pada setiap tingkat pendidikan, mulai dari TK sampai Perguruan Tinggi, serta terjadi hampir di semua Negara. Penelitian yang dilakukan oleh Lai, Ye, dan Chang (2008) di 10 negara di Asia-Pasifik pada 54.383 orang siswa tingkat delapan yang terdiri dari siswa Australia (4.614 subjek), Hong Kong (4.935 subjek), Indonesia (5.542 subjek), Jepang (4.835 
subjek), Korea (5.287 subjek), Malaysia (5.287 subjek), New Zaeland (3.652 subjek), Philipina (6.840 subjek), Singapura (6.008 subjek), dan Taiwan (5.373 subjek). Hasilnya menunjukkan bahwa perilaku bullying ditemukan di semua Negara, yang paling tinggi adalah Philipina dan yang paling rendah adalah Korea dan Jepang. Sedangkan Indonesia, perilaku bullyingnya berada pada kategori sedang dibanding Negara-negara lainnya.

Bullying adalah perilaku agresif yang dilakukan oleh individu atau kelompok yang lebih kuat terhadap individu atau kelompok yang lebih lemah, yang bertujuan untuk menyakiti dan dilakukan secara berulangulang. ${ }^{2}$ Siswa yang terlibat dalam perilaku bullying sangat banyak, baik sebagai pelaku, korban, maupun sebagai pelaku sekaligus korban. Penelitian Nansel, dan kawankawan³ sebelumnya menemukan bahwa 29,9\% dari 15.686 siswa kelas 6 - 10 di Amerika terlibat perilaku bullying, yaitu $13 \%$ sebagai pelaku, 10,6\% sebagai korban, dan $6,3 \%$ menjadi pelaku sekaligus korban. Siswa laki-laki maupun perempuan memiliki risiko terlibat perilaku bullying, baik sebagai pelaku, korban atau keduanya. Selanjutnya Kowalski dan Limber (2013) yang melakukan penelitian pada 903 siswa kelas 6 - 12 pada dua sekolah di Pennsylvania juga menemukan bahwa sebanyak 132 siswa (14,6\%) pernah setidaknya satu kali menjadi korban, $156(17.3 \%)$ menjadi pelaku, dan 173 (19.2\%) menjadi pelaku sekaligus korban bullying dalam dua bulan terakhir. Selanjutnya, penelitian tersebut juga menemukan bahwa 76 (8.4\%) menjadi korban, 74 (8.2\%) menjadi pelaku, dan 33 (3.7\%) menjadi pelaku sekaligus korban dengan frekuensi dua sampai tiga kali atau lebih dalam dua bulan terakhir.Di Pekanbaru juga ditemukan bullying baik di SD, SMP, maupun SMU (Wahyuni \& Nazifah, 2012). ${ }^{4}$

Penelitian sebelumnya juga menemukan bahwa, perilaku bullying ini memiliki dampak terhadap korban, antara lain meningkatkan gejala-gejala emosional misalnya merasa tidak bahagia, tertekan dan sangat sedih (Malti, Perren, \& Buchmann, 2010)5, depresi yang mana semakin sering terkena bullying maka semakin tinggi tingkat depresinya (Uba, Yaacob, \& Juhari, 2009) ${ }^{6}$, rendahnya harga diri (Uba, dkk., 2010) ${ }^{7}$, meningkatkan stress (Konishi \& Hymel, 2009) ${ }^{8}$. Selain itu, pengalaman bullying di sekolah juga memiliki dampak yang terhadap performansi siswa di sekolah, seperti yang ditemukan oleh Totura, dkk.(2009) ${ }^{9}$ bahwa baik pelaku maupun korban bullying memiliki performansi akademik yang rendah.Glew, dkk. $(2005){ }^{10}$ menemukan bahwa siswa yang menjadi korban bullying memiliki prestasi akademik yang rendah, merasa tidak aman di sekolah, merasa tidak 
memiliki sekolahnya, dan merasa sedih, dibandingkan siswa yang tidak menjadi korban bullying.Siswa yang menjadi pelaku bullying juga siswa yang merasa tidak aman dan sedih, kemudian mengganggu temannya sehingga terjadi pertengkaran. Selanjutnya siswa tersebut juga akan menjadi pelaku sekaligus korban bullying.

Penelitian sebelumnya menemukan bahwa ada dua faktor yang mempengaruhi anak berperilaku bullying, yaitufaktor internal danrespon eksternal. Faktor internal antara lain, kemampuan berempati, kemampuan mengendalikan diri, sikap terhadap perilaku kekerasan, dan sikap terhadap permusuhan. Sedangkan faktor eksternal antara lain, pola asuh orangtua, kelekatan antara anak dan orangtua, iklim sekolah, dan lingkungan (Jocobs, 2006: Pontzer, 2010; Shechtman, 2003; \&Ahmed \& Braithwaite, 2004) ${ }^{11}$.

Orangtua khususnya ibu berperan sebagaifaktor sentral dalam proses perkembangan anak. Malekpour $(2007)^{12}$ mengatakan bahwa hubungan antara orangtua dan anak pada awal kehidupan anak berpengaruh terhadap kematangan otak anak.Anak yang memperoleh kelekatanyang aman (secure attachment) memiliki pertumbuhan dan kematangan otak yang lebih baik, sedangkan anak yang mengalami kelekatan yang tidak aman (insecure attachment) cenderung mengalami psikopatologi.Kualitas kelekatan seorang anak sangat ditentukan oleh bagaimana seorang ibu memperlakukannya. Sikap ibu yang kurang responsif berkaitan dengan hubungan anak dan ibu yang tidak aman diasosiasikan dengan gangguan kelekatan (Smith, 2004) ${ }^{13}$.

Schneider, Atkinson, dan Tardif (2001) ${ }^{14 j u g a ~ m e n e m u k a n ~ b a h w a ~ a n a k ~}$ yang memiliki kelekatan yang bagus dengan orangtuanya memiliki kemampuan menjalin hubungan pertemanan yang bagus, baik dengan teman sebayanya maupun dengan orang-orang yang dikenalinya. Appleyard \& Berlin (2007) $)^{15}$ mengungkapkan bahwa kualitas attachment berpengaruh terhadap perkembangan anak. Dimana anak yang mengalami secure attachment memiliki kesehatan sosial, emosional, kognitif, dan motivasi yang tinggi. Anak yang ketika bayi memperoleh secure attachment dengan orangtuanya, ketika memasuki usia kanak-kanak ia menjadi lebih mandiri dan percaya diri, mampu menyesuaikan diri dengan temanteman sebaya dan guru, mampu berkonsentrasi, rasa ingintahu yang tinggi dan motivasi di sekolah, serta memiliki kemampuan problem solving yang tinggi.Sedangkan anak yang mengalami insecure attachment cenderung mengalami masalah dalam perkembangan dan penyesuaiannya, keterampilan sosialnya buruk, misalnya menarik diri atau agresif, keterampilan berkomunikasinya buruk, tidak 
responsif, mudah terganggu, kurang rasa ingin tahu, dan motivasi berprestasinya kurang.

Menurut Ervika (2005) ${ }^{16} \mathrm{ibu}$ yang memiliki perilaku yang responsif dan konsisten serta dapat memberikan perlakuan pemeliharaan fisik yang tepat dalam memenuhi kebutuhan anak dikatakan memiliki perilaku keibuan yang akan membuat anaknya membentuk kualitas kelekatan yang aman (secure attachment) dalam hal ini akan membantu anak melewati proses dan mencapai perkembangan optimal, sebaliknya ibu yang tidakresponsif, tidak sensititif dan tidak konsisten serta tidak dapat memenuhi kebutuhan anaknya dapat membuat anak mengalami gangguan kelekatan (attachment disorder) karena memiliki kualitas kelekatan yang tidak aman (insecure attachment).

Walden dan Beran (2010) ${ }^{17}$ melakukan penelitian tentang hubungan antara kualitas kelekatan orangtua dengan kecenderungan perilaku bullying pada anak SD, dan menemukan bahwa kualitas kelekatan yang rendah memiliki korelasi dengan kecenderungan anak untuk menjadi pelaku dan korban bullying, begitu juga sebaliknya, kualitas kelekatan yang tinggi dapat menghindarkan anak dari menjadi pelaku dan korban bullying.Pei $(2011)^{18}$ juga menemukan bahwa anak yang memiliki pengalaman kelekatan yang kurang nyaman (insecure attachment) dan kurangnya kehangatan dengan orangtuanya cenderung melakukan perilaku agresif.

Orangtua khususnya ibu berperan sebagairespon sentral dalam proses perkembangan anak. Namun, pada zaman sekarang banyak ibu yang bekerja baik dalam instansi formal maupun non formal.Pekerjaan membuat ibu harus meninggalkan anaknya sementara waktu untuk diasuh oleh orang lain yang dipercaya. Orang itu akan menggantikan peran ibu dalam melakukan pengasuhan, yang biasanya merupakan keluarga maupun dari luar keluarga. Peraturan pemerintah tentang hak cuti hamil dan melahirkan bagi ibu hanya tiga bulan, sehingga anak hanya tiga bulan menjalin kelekatan dengan ibunya.Selanjutnya anak biasanya diasuh oleh nenek, tante, atau pengasuhnya. Jam kerja ibu yang panjang, yaitu mulai pukul 07.30 WIB hingga 16.00 WIB membuat intensitas kebersamaan antara anak dengan ibu menjadi berkurang. Hal ini juga akan mempengaruhi terhadap kelekatan antara ibu dan anak, dan akhirnya berpengaruhi terhadap interaksi sosial anak dengan teman-teman sebaya.

Oleh karena itu, penelitian ini ingin mengetahui apakah ada hubungan antara kualitas kelekatanantaraanakdanibuyang bekerja dengankecenderungan anakuntuk menjadi pelaku dan korban bullying?

\section{TINJAUAN PUSTAKA}

Bullying 
Perilaku bullying merupakan tindakan agresif yang dilakukan secara sengaja oleh individu atau kelompok teman sebaya yang lebih kuat terhadap individu atau kelompok teman sebaya yang lebih lemah, baik secara fisik, verbal, atau psikologis dan dilakukan secara berulang-ulang serta menimbulkan dampak negatif bagi korbannya (Olweus, 2003 ${ }^{19}$; Lines, 200820; Papalia, Olds and Feldman, $2007^{21}$; Kazdin, 200022; Eisenberg, 2006) ${ }^{23}$.

Ada beberapa bentuk perilaku yang terlihat pada tindakan bullying yaitu memukul atau memanggil nama seseorang yang membuat orang tersebut menjadi marah, tersakiti, atau merasa terganggu (Liness, 2008) ${ }^{24}$. Olweus (2003) ${ }^{25}$ juga menjelaskan beberapa bentuk perilaku bullyingyang membedakannya dengan perilaku agresif secara umum, antaralain: (1). Adanya perilaku agresif dan sengaja "melakukan kejahatan", (2). Dilakukan secara berulang-ulang atau berkali-kali, (3). Hubungan interpersonal yang ditandai dengan ketidakseimbangan kekuatan, dan (4). Mengakibatkan dampak negatif bagi korban (Krahe, 2005'26; Houbre, dkk., 2006; Houbre, dkk., 2010). ${ }^{27}$

Berdasarkan penjelasan di atas dapat disimpulkan bahwa ciri-ciri perilaku bullying meliputi (1). Adanya perilaku agresif yang sengaja dilakukan, (2). Dilakukan berulang-ulang, (3).Adanya ketidakseimbangan kekuatan antara pelaku dan korban, dan (4).Mengakibatkan dampak negatif bagi korban.

Pada saat terjadi bullying di sekolah, ada tiga peran yang dimainkan oleh siswa, yaitu sebagai pelaku, korban, pelaku-korban, dan saksi bullying (bystander). Pelaku adalah siswa yang melakukan perilaku bullying terhadap siswa lain. Karakteristik pelaku bullying meliputi pelaku memiliki fisik yang lebih kuat dibandingkan siswa lainnya, kurang mampu memahami dan merasakan apa yang dirasakan oleh oranglain, memiliki sikap positif terhadap kekerasan, agresif terhadap teman sebaya dan orang dewasa, akrab dengan pelaku, kurang mampu mengontrol diri, cenderung mendominasi, tidak mau mentaati norma sosial, sering memaksa korban, perilaku kurang baik di sekolah dan sering dikeluarkan dari sekolah, memiliki kelompok, berasal dari keluarga yang mengabaikan, keras, dan otoriter, serta ada riwayat perilaku bullying (Olweus, 2003'28; Cunningham, 200729; Eisenberg, 2006; Baldry \& Farrington, 200030; Rigby, 2003 ${ }^{31}$; Wahyuni, 2012). ${ }^{32}$

Korban adalah siswa yang menjadi sasaran tindakan bullying. Olweus (2003) ${ }^{33}$, melabel korban bullying sebagai orang yang pasif dan bersikap tunduk. Sikap korban pasif dan tunduk terhadap orang yang tidak aman bagi mereka dan merasa tidak berharga serta tidak akan membalas jika mereka 
dihina. Eisenberg (2006) ${ }^{34}$ juga mengungkapkan bahwa anak yang memiliki risiko menjadi korban bullying adalah anak yang menghindar dari perilaku agresif, menarik diri dari interaksi sosial, pendiam secara sosial dan pencemas.Pelaku-korban adalah siswa yang menjadi pelaku sekaligus menjadi korban perilaku bullying.

Bystander adalah orang yang menyaksikan kejadian bullying (Rigby \& Johnson, 2005) $)^{35}$.Dalam menghadapi situasi bullying, bystander memiliki sikap dan perilaku yang berbeda-beda, antara lain (a), Mendukung dan membela korban secara langsung. Bystander tipe ini memilih untuk membela dan mendukung korban secara langsung, memiliki pandangan bahwa perilaku bullying itu adalah salah dan tidak adil, dapat merasakan rasa sakit yang dirasakan oleh korban, memiliki empati terhadap korban, korban adalah temannya karena jika tidak kenal biasanya enggan untuk membantu, dan memiliki sikap yang ingin membantu dan suka membantu orang lain. (b), Mendukung korban secara tidak langsung, yaitu membantu korban dengan cara melaporkan kejadian bullying kepada guru, (c), Tidak peduli terhadap korban. Bystander tipe ini memilih untuk tidak peduli menganggap bahwa itu bukan urusannya, takut akan konsekuensi yang akan diterimanya dari pelaku, merasa bahwa itu adalah tanggung jawab korban untuk membela dirinya sendiri, berpikir bahwa melaporkan kejadian kepada guru hanya akan siasia, dan merasa bahwa kejadian bullying merupakan sesuatu yang lucu untuk ditonton, dan (d), Mendukung pelaku. Bystander yang memilih untuk mendukung pelaku, hal ini dilakukan karena mereka mencari aman dan menghindari risiko dari pelaku, merasa kagum terhadap pelaku bullying dan menganggap pelaku agresivitas adalah orang yang keren.

Sejiwa $(2008)^{36}$ membagi bullying menjadi tiga bentuk yaitu: bullying fisik, bullying verbal, dan bullying mental atau psikologis.

a) Bullying fisik merupakan perilaku agresif yang dilakukan secara fisik, misalnya menampar, menimpuk, menginjak kaki, menjegal, meludahi, memalak, melempar dengan barang, menyuruh, menghukum dan mendorong.

b) Bullying verbal yaitu perilaku bullying yang dilakukan secara verbal atau kata-kata, misalnya, memaki, menghina, menjuluki, meneriaki, mempermalukan di depan umum, menuduh, menyoraki, menebarkan fitnah dan menolak.

c) Bullying mental atau psikologis yaitu perilaku bullying yang dilakukan dalam bentuk memandang sinis, memandang penuh ancaman, mempermalukan di depan umum, 
mendiamkan, mengucilkan, meneror lewat pesan pendek telepon genggam atau e-mail, memandang dengan pandangan merendahkan, memelototi, dan mencibir.

\section{Kelekatan (Attachment)}

Setiap bayi mengembangkan kelekatan (attachment) dengan orangtuanya.Kelekatan ini berkembang pada tahun pertama kehidupan bayi dan terus berlanjut sesuai dengan interaksi antara orangtua dan anak (Appleyard \& Berlin, 2007) ${ }^{37}$. Menurut Jhon Bowlby, ahli yang mencetuskan istilah kelekatan (attachment) dalam perkembangan anak pada tahun 1940-an menjelaskan bahwa kelekatan adalah kehangatan, keintiman, dan hubungan yang berkelanjutan antara ibu dan bayi, dan hubungan tersebut memunculkan kepuasan dan kebahagiaan (Centre for Parenting \& Research, 2006; Malekpour, 2007). ${ }^{38}$

Ada dua macam bentuk kelekatan, yaitu kelekatan yang aman (secure attachment) dan kelekatan yang tidak aman (insecure attachment) (Appleyard \& Berlin, 2007; Malekpour, $2007)^{39}$. Kelekatan yang aman memiliki karakteristik kemampuan anak untuk menggunakan orangtuanya sebagai sumber rasa nyaman dan dasar dari rasa aman. Prinsip pokok dari teori kelekatan adalahdaridependenmenuju independen, maksudnya ketika anak merasa percaya dengan keberadaan orangtuanya, maka ia dapat mengeksplorasi dirinya secara penuh (Appleyard \& Berlin, 2007) ${ }^{40}$.Dalam membentuk hubungan yang hangat antara orangtua dan anak, maka ada dua hal mendasar yang harus dipenuhi, yaitu 1). Pembentukan kepercayaan (basic of trust) semenjak bayi, hal ini akan terbentukjika orangtua selalu ada kapanpun bayi membutuhkan. 2). Memberikan penghargaan terhadap regulasi emosi, yang mana dalam mengekspresikan perasaanya, terus menerus yang didasarkan dengan pola fisiologis (Malekpour, 2007) ${ }^{41}$.

Ada beberapa respon perilaku orangtua yang berkaitan dengan kelekatan yang aman (secure attachment), yaitu 1).Responsif, 2).Jelas, konsisten, harapan yang tepat terhadap perkembangan dan memberikan pengawasan, 3).Hangat, berinteraksi secara positif dan memberikan respon verbal yang baik, 4). Melihat anak sebagai individu yang unik, memahami anak (misalnya, kenapa ia melakukan itu, apa yang dia lakukan), dan 5) Merespon anak dengan penuh perasaan. Sedangkan perilaku bayi dan anak-anak yang berkaitan dengan kelekatan yang aman adalah 1).Merasa nyaman dalam mengeksplorasikan diri dengan orang yang lekat dengannya, 2). Ketika merasa gelisah atau sakit, maka ia pergi kepada orang yang lekat dengannya untuk mencari kenyamanan (misalnya, bukan orang yang tidak dia kenali), 3). Mencari bantuan jika ia membutuhkannya, 4). Mau menuruti permintaan untuk 
meminimalisasi konflik, 5). Tidak begitu membutuhkan control yang berlebihan dari pengasuh.

Kelekatan yang tidak aman (insecure attachment) memiliki karakteristik antara lain ketidakmampuan anak untuk menjadikan orangtuanya sebagai dasar rasa nyaman. Ada tiga tipe perilaku kelekatan yang tidak aman, yaitu 1).Sebagian besar anak cenderung tidak mandiri, sulit berpisah dengan orangtuanya, dan tidak mandiri saat bermain.Kelekatan ini dinamakan dengan insecure-resistant attachment.2).Beberapa anak agak tergantung, tidak dekat dengan orangtuanya dan tidak peduli ketika orangtuanya pergi.Bentuk kelekatan ini disebut dengan insecure-avoidant attachment.3). Anak memperlihatkan kelekatan yang kacau dengan orangtuanya, yang terlihat dari kebingungan dan perilaku yang tak beraturan di depan orangtuanya. Bentuk kelekatan ini disebut dengan disorganized atau disoriented attachment.

Selanjutnya, ciri-ciri perilaku orangtua yang berkaitan dengan kelekatan yang tidak aman (insecure attachment), adalah 1).Tidak membiarkan anak melakukan eksplorasi diri, terlalu mengontrol anak, 2). Perilaku orangtua tidak jelas, tidak konsisten, harapanyang berlebihan terhadap anak, sangat mengawasi, 3). Mengabaikan kebutuhan dan isyarat anak, 4).Tidak konsisten, respon perilaku orangtua tidak terandal (tidak reliable), 5).Perilaku bermusuhan, mengancam, dan menakutkan, 6).Lebih memprioritaskan kebutuhan orangtua daripada kebutuhan anak (egois), 7).Berperilaku seperti anak kecil atau memperlakukan anak seolah-olah anak yang bertanggungjawab (orangtua yang seolah-olah jadi anak, anak yang jadi orangtua), 8).Penarikan diri yang ditandai dengan ketakutan, keraguraguan dan ketakutan ketika berada di sekitar anak, 9).Terlalu dekat dengan anak atau adanya perilaku seksual yang kurang wajar.

Sedangkan perilaku anak yang berkaitan dengan kelekatan yang tidak aman adalah1) sangat tergantung, 2).Pemalu, menarik diri, atau tidak bisa menjalin pertemanan, 3).Tidak mampu mencari seseorang untuk memperoleh rasa aman jika diperlukan, 4).Terlalu ramah bahkan kepada orang yang tidak dikenal, 5). Memiliki sifat yang suka menghukum dan memerintah orang lain, 6). Lebih mementingkan kepentingan orangtuanya, 7).Takut kepada orangtuanya, seperti mendekati sambil menjauh, diam, dan kaku, 8). Memiliki kecenderungan perilaku seksual.

\section{Hipotesis Penelitian}

Hipotesis dalam penelitian ini adalah "ada hubungan antara kualitas kelekatan (attachment) dengan ibu yang bekerja dengan kecenderungan anak 
untuk menjadi pelaku dan korban bullying".

\section{METODE PENELITIAN}

\section{Variabel Penelitian}

Variabel Bebas : Kualitas Kelekatan

Variabel Terikat:

a. Kecenderungan anak menjadikorban bullying

b. Kecenderungan anak menjadi pelaku bullying

\section{Defenisi Operasional}

Defenisi operasional bertujuan meletakkan arti pada suatu konstruk atau variabel dengan cara menetapkan kegiatan-kegiatan atau tindakan yang perlu untuk mengukur konstruk atau variabel tersebut (Kerlinger, 1990 ${ }^{42}$. Adapun defenisi operasional dari variabel penelitian ini adalah sebagai berikut:

a. Variabel Bebas

Kualitas kelekatan adalah tindakan yang dilakukan oleh seorang ibu dalam merawat, mengasuh, membesarkan anak.Perawatan, pengasuhan dan pola membesarkan anak yang sensititif, responsif, konsisten dan memenuhi kebutuhan dasar anak merupakan kualitas kelekatan yang aman (secure attachment). Sebaliknya pola perawatan, pengasuhan dan membesarkan anak yang tidak Responsif, tidak konsisten dan tidak memenuhi kebutuhan dasar anak merupakan kualitas kelekatan yang tidak aman (insecure attachment).

b. Variabel Terikat

1. Kecenderungan anak menjadi korban bullying adalah kecenderungan anak untuk menjadi sasaran dari perilaku agresif dari orang lain yang akan membuat anak menjadi tersakiti sehingga terlihat sedih, murung, suka menangis, malas atau menolak ke sekolah.

2. Kecenderungan anak menjadi pelaku bullying adalah kecenderungan anak untuk dengan sengaja melakukan tindakan agresif yang bertujuan menyakiti atau melukai orang lain sehingga sering tampak dalam perilakunya berkata kasar, memukul, bahkan merampas hak milik orang lain.

Subjek dalam penelitian ini adalah siswa sekolah dasar kelas IV, V, dan VI dari enam Sekolah Dasar di Pekanbaru, yang berusia sekitar 9-12 tahun yang memiliki ibu yang bekerja baik di instansi pemerintah, swasta, maupun berwirausaha mandiri.

Alat ukur yang digunakan dalam penelitian ini adalah skala kelekatan dengan ibu bekerja yang disusun oleh Armsden dan Greenberg (2009) ${ }^{43}$ yaitu Inventory of Parent and Peer Attachment (IPPA), dan skala kecenderungan menjadi pelaku dan korbanbullyingyang disusun berdasarkan 
bentuk-bentuk perilaku bullying yang disusun oleh Sejiwa $(2008)^{44}$.

Metode Analisis Data

Analisis data yang digunakan dalam penelitian ini adalah menggunakan analisis korelasi product moment by Pearson dan uji-t untuk melihat perbedaan kelekatan, kecenderungan menjadi pelaku dan korban bullying berdasarkan kelas, jenis kelamin, dan jumlah jam kerja ibu.

\section{HASIL DAN PEMBAHASAN}

Penelitian ini dilakukan pada pada enamSD diPekanbaru, Riau.Jumlah skala yang disebarkan adalah 1690 skala terhadap 1690 siswa.Selanjutnya jumlah subjek yang sesuai dengan kriteria adalah 336 siswa.

Tabel 1. Deskripsi Statistik Variabel

\begin{tabular}{|c|c|c|c|c|c|c|c|}
\hline Variabel & $\mathbf{N}$ & Range & $\underset{\text { um }}{\operatorname{Minim}}$ & Maximum & $\begin{array}{c}\text { Mean } \\
\text { Empirik }\end{array}$ & $\begin{array}{c}\text { Mean } \\
\text { Hipotettik }\end{array}$ & Std. Deviation \\
\hline Attachment total & 336 & 17.00 & 31.00 & 48.00 & 42.9196 & 32 & 3.67030 \\
\hline $\begin{array}{l}\text { Parent } \\
\text { Communication }\end{array}$ & 336 & 8.00 & 7.00 & 15.00 & 13.1310 & 12 & 1.77397 \\
\hline Parent Trust & 336 & 7.00 & 11.00 & 18.00 & 16.4881 & 10 & 1.55875 \\
\hline Parent Alienation & 336 & 6.00 & 9.00 & 15.00 & 13.3006 & 10 & 1.54981 \\
\hline Bullying & 336 & 18.00 & 10.00 & 28.00 & 13.2202 & 25 & 3.12797 \\
\hline Victimization & 336 & 18.00 & 9.00 & 27.00 & 16.1161 & 22.5 & 3.59538 \\
\hline
\end{tabular}

Hasil Korelasi

Pada tabel 2 dijelaskan tentang korelasi antar variabel. Skor kelekatan total berkorelasi secara sangat signifikan dengan kecenderungan menjadi pelaku (bullying) (p 0,001 dan $\mathrm{R}-0,288$ ) dan korban bullying (victimization)(p 0,001 dan $\mathrm{R}-0,185)$. Hal ini menunjukkan bahwa tingginya kualitas kelekatan antara anak dengan ibunya yang bekerja akan menurunkan kemungkinan anak menjadi pelaku atau korban bullying.
Aspek-aspek kelekatan yang terdiri dari komunikasi, kepercayaan, dan menghindari juga berkorelasi secara sangat signifikan dengan bullying ( $p$ 0,004 R -0,156; p 0,001 R -0,185; p 0,001 R $-0,317)$. Artinya, komunikasi dan kepercayaan yang tinggi terhadap ibu dapat meminimalisasi kecenderungan anak menjadi pelaku bullying. Sedangkan untuk kecenderungan menjadi korban bullying, tidak semua aspek kelekatan memiliki korelasi yang 
signifikan.Aspek komunikasi dengan ibu tidak berkorelasi dengan kecenderungan anak menjadi korban bullying ( $\mathrm{p} 0,477)$, aspek yang berkorelasi secara signifikan adalah aspek kepercayaan dan penghindaran terhadap ibu (p 0,001 R-0,178; p 0,001 R $-0,213)$. Selanjutnya, hasil penelitianjuga menunjukkan bahwa anak yang cenderung menjadi korban juga akan cenderung menjadi pelaku ( $\mathrm{p} 0,001 \mathrm{R}$ $0,395)$

Tabel 2.Analisis Korelasi Product Moment Pearson

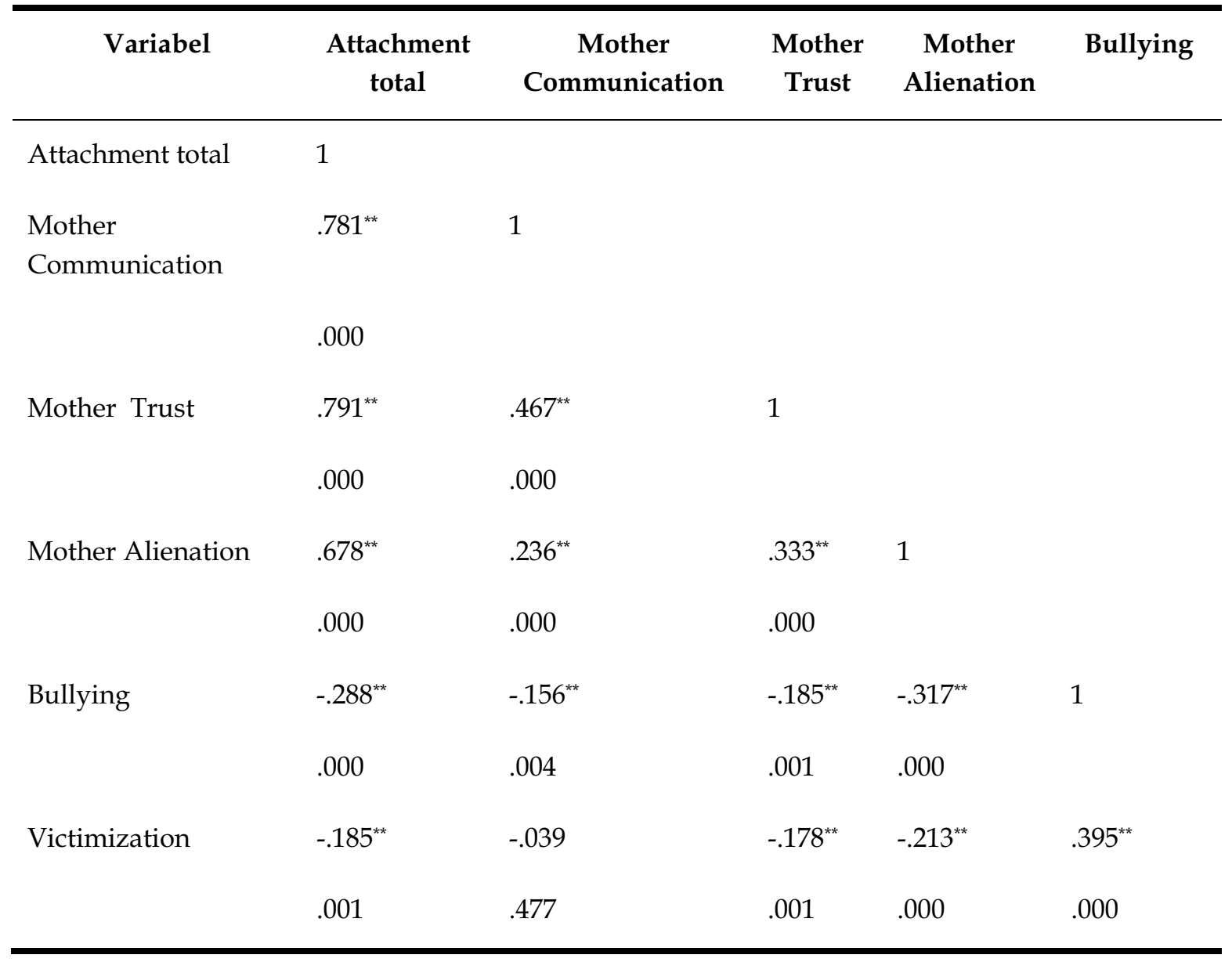

Pada tabel 3 dijelaskan tentang perbedaan kelekatan, aspek-aspek kelekatan, kecenderungan menjadi pelaku dan korban bullying berdasarkan kelas, jenis kelamin, dan lamanya ibu bekerja. Hasil penelitian menunjukkan bahwa terdapat perbedaan yang sangat signifikan kecenderungan menjadi pelaku bullying berdasarkan kelas ( $\mathrm{p}$ 0,014), siswa kelas 5 dan 6 lebih tinggi kecenderungan menjadi pelaku bullying dibanding siswa kelas 4 (rerata kelas 4, 5, dan 6 secara berurutan adalah 12,5179 ; 13,5630; 13,5843). Tinjauan berdasarkan 
jenis kelamin ditemukan bahwa siswa laki-laki lebih intensif berkomunikasi dengan ibunya yang bekerja dibanding siswa perempuan (rerata laki-laki 13,3314, rerata perempuan 12,913; dan p 0,031$)$. Selain itu juga ditemukan bahwa siswa laki-laki lebih tinggi kecenderungan menjadi pelaku bullying dibanding siswa perempuan (rerata laki-laki 13,7485, rerata perempuan 12.6459; dan p 0,001), sedangkan untuk kecenderungan menjadi korban bullying ditemukan tidak ada perbedaan antara siswa laki-laki dan siswa perempuan. Hasil analisis selanjutnya menunjukkan bahwa terdapat perbedaan kelekatan antara anak dengan ibu, berdasarkan lamanyajam kerja ibu (p 0,034). Ibu yang bekerjanya kurang dari 5 jam dalam 1 hari memiliki rerata kelekatan yang lebih rendah dibanding ibu yang bekerja lebih dari 5 jam dalam 1 hari. Namun, anak yang memiliki ibu bekerja yang sangat lama memiliki kecenderungan menjadi korban (ibunya bekerja lebih dari 20 jam dalam 1 hari).

Tabel 3.Perbedaan Kelompok Berdasarkan Kelas, Jenis Kelamin, dan Jumlah Jam Kerja Ibu ( $N=336$ siswa)

\begin{tabular}{|c|c|c|c|c|c|}
\hline Sumber & $\begin{array}{l}\text { JK (Sum of } \\
\text { Squares) }\end{array}$ & $\mathrm{db}(\mathrm{df})$ & $\begin{array}{c}\text { RK } \\
\text { (Mean of } \\
\text { Squares) }\end{array}$ & $\mathbf{F}$ & $\mathrm{p}$ \\
\hline
\end{tabular}

Attachment total

- Kelas

- Jenis Kelamin

- Jumlah Jam Kerja Ibu

Mother Communication

- Kelas

- Jenis Kelamin

- Jumlah Jam Kerja Ibu

Mother Trust

- Kelas

- Jenis Kelamin

- Jumlah Jam Kerja Ibu
5,648

8,100

161,251

5,907

14,678

38,623

2,362

0,372

22,617
2

2,824

0,209

0,812

8,100

0,601

0,439

$5 \quad 32,250$

2,446

0,034 
Sri Wahyuni \& Yulita KA: Kecenderungan Anak Menjadi Pelaku dan Korban Bullying Ditinjau dari Kualitas Kelekatan dengan Ibu yang Bekerja

Mother Alienation

- Kelas

- Jenis Kelamin

- Jumlah Jam Kerja Ibu
3,399

2,543

4,574

2

1,699

$1 \quad 2,543$

5

0,915

0,377

0,864

Bullying

- Kelas

- Jenis Kelamin

- Jumlah Jam Kerja Ibu
82,905

101,945

12,659

2

41,453

1

101,945

$5 \quad 2,532$

0,256

0,937

Victimization

- Kelas

- Jenis Kelamin

- Jumlah Jam Kerja Ibu
10,008

11,974

359,498
25,004

0,386

0,680

$1 \quad 11,974$

0,926

0,337

$5 \quad 71,900$

0,000

\section{PEMBAHASAN}

Tujuan penelitian ini adalah untuk mengetahui hubungan antara kelekatan anak dengan ibu yang bekerja dengan kecenderungan berperilaku bullying dan menjadi korban bullying (victimization).Penelitian ini merupakan replikasi dari penelitian yang dilakukan Walden dan Beran (2010) ${ }^{45}$ yang menemukan bahwa rendahnya kualitas kelekatan antara anak dengan pengasuhnya, maka meningkat kemungkinan anak menjadi pelaku dan korban bullying. Perbedaannya penelitian kita ini dengan penelitian Walden dan Beran (2010) ${ }^{46}$ adalah pada subjeknya, yang mana pada penelitian ini subjeknya adalah anak yang memiliki ibu bekerja.

Pada penelitian ini ditemukan bahwa ada hubungan negatif yang sangat signifikan antara kualitas kelekatan dengan ibu yang bekerja dengan kecenderungan anak menjadi pelaku dan korban bullying. Bagi anak di Indonesia khususnya, sosok ibu adalah pengasuh utama dan merupakan subjek kelekatan yang paling dominan dibandingkan dengan orang lain. Kelekatan antara anak dan orangtua akan mempengaruhi hubungan interpersonal anak sepanjang rentang kehidupannya (Schneider, Atkinson, \& Tardif, 2001) ${ }^{47}$. Anak yang memiliki kelekatan yang aman (secure attachment) dengan ibunya menjadikan ibunya 
sebagai tempat mencari kenyamanan ketika merasa tertekan atau gelisah (Centre for Parenting \& Research, 2006). Anak yang memperoleh kelekatan yang aman memiliki pengalaman interaksi yang hangat, konsisten, emosi yang positif dengan pengasuh, selanjutnya anak menjadi mampu melakukan hubungan sosial yang positif dengan orang lain dan lebih produktif (Weinfield et al.1999, dalam Walden dan Beran, 2010 ${ }^{48}$. H. Van IJzendoorn $(1997)^{49}$ juga menemukan bahwa kelekatan mempengaruhi perkembangan perilaku moral, sifat otoriter, dan perilaku kriminal anak pada usia remaja dan dewasa. Anak yang memiliki kelekatan yang aman cenderung menjadi lebih empati dan berperilaku sosial yang baik dibanding anak yang memiliki kelekatan yang tidak aman (insecure attachment).Anak yang memiliki kelekatan yang tidak aman ini cenderung melakukan perilaku agresif atau perilaku anti sosial ketika remaja dan dewasa. Kõiv (2012) $)^{50}$ menemukan bahwa anak yang cenderung menjadi pelaku bullying memiliki kelekatan yang bersifat menghindari (avoidant attachment), sedangkan korban bullying memiliki kelekatan yang tidak aman (insecure attachment).

Pada penelitian ini tampak bahwa kualitas kelekatan antara anak dan ibunya yang bekerja berada pada kategori tinggi (rerata empirik lebih tinggi daripada rerata hipotetik), hal ini menunjukkan bahwa status ibu yang bekerja tidak berpengaruh terhadap kelekatan ibu dengan anaknya.Pada penelitian ini juga tampak bahwa ibu yang bekerja kurang dari 5 jam dalam 1 hari memiliki kelekatan aman yang lebih rendah dibanding ibu yang bekerja lebih dari 5 jam dalam 1 hari. Yang penting adalah adanya komunikasi antara orangtua dan anak. Walaupun ibunya berada jauh dari anak, namun jika komunikasi terjalin dengan baik maka akan terbentuk kelekatan yang aman antara ibu dan anak.O'Reilly $(2012)^{51}$ menemukan bahwa tidak terdapat hubungan antara status ibu bekerja dengan kualitas kelekatan dan kemampuan kognitif anaknya.Huston dan Aronson (2005) ${ }^{52}$ juga menemukan bahwa tidak ada korelasi antara lamanya waktu kebersamaan antara ibu dan anak dengan kelekatan yang aman antara anak dengan ibu yang bekerja, yang lebih penting adalah lingkungan rumah yang nyaman.

Analisis perbedaan jenis kelamin ditemukan beberapa hal dalam penelitian ini. Pada aspek-aspek kelekatan tampak bahwa hanya aspek komunikasi dengan ibu yang berbeda antara anak laki-laki dengan anak perempuan. Anaklaki-laki berkomunikasi lebih intensif dengan ibunya yang bekerja dibanding anak perempuan. Walaupun demikian, anak laki-laki lebih tinggi kecenderungan menjadi pelaku bullying dibanding anak perempuan.Hasil 
penelitian ini berbeda dengan hasil penelitian yang ditemukan oleh Walden dan Beran (2010) ${ }^{53}$ yaitu tidak ada perbedaan kecenderungan anak menjadi pelaku bullying antara anak laki-laki dan anak perempuan. Selanjutnya juga ditemukan bahwa perilaku bullying lebih tinggi frekuensinya pada kelas yanglebih tinggi dibanding kelas yang lebih rendah (kelas VI lebih tinggi dibanding kelas IV dan V).

Implikasi dari hasil penelitian ini adalah kualitas kelekatan yang rendah antara anak dengan ibunya yang bekerja mengakibatkan anak cenderung melakukan dan menjadi korban bullying dibanding siswa yang memiliki kualitas kelekatan yang tinggi.

\section{Endnotes}

1 Konishi, C\& Hymel, S. (2009). Bullying and Stress in Early Adolescence: The Role of Coping and Social Support. Journal of Early Adolescence, 29 (3) 333-356.

2 Lines, D. (2008). The bullies, understanding bullies and bullying. London \& Philadelphia: Jessica Kingsley Publishers.

3 Nansel, T. R., Overpeck, M., Pilla, R. S., Ruan, W. J., Simons-Morton, B., \& Scheidt, P. (2001). Bullying behaviors among U.S. youth: Prevalence and association with psychosocial adjustment. Journal of the American Medical Association, 285, 2094-2100.

4 Wahyuni, S. \& Nazifah, N. 2012. Studi crosssectional perilaku bullying pada siswa SD, SMP, dan SMU di kota Pekanbaru Riau.Hasil Penelitian, dipresentasikan pada Temu Ilmiah Ikatan Psikologi Sosial, di Pekanbaru pada tanggal 02 November 2012.

5 Malti, T., Perren, S. \& Buchmann, M. (2010).Children's Peer Victimization, Empathy, and Emotional Symptoms. Child Psychiatry Hum Dev, 41:98-113.

6 Uba, I., Yaacob, S.N., \& Juhari, R. (2009).The Relationship between Peer Relations and Depression among Adolescents in Selangor,
Malaysia.European Journal of Social Sciences, 11 (1), 149-159.

7 ibid

8 Konishi, C \& Hymel, S., op.cit (2009).

9 Totura, C., M., W., MacKinnon-Lewis, C., Gesten, E.L., Gadd, R., Divine, K.P., Dunham, S. \& Kamboukos, D. (2009).Bullying and Victimization Among Boys and Girls in Middle School: The Influence of Perceived Family and School Contexts. Journal of Early Adolescence, 29 (4), 571609.

10 Glew, G.M., Fan, M-Y., Katon, W., Rivara, F.P., Kernic, M.A., (2005). Bullying, psychosocial adjustment, and academic performance in elementary school.Arch Pediatr Adolesc Med, 159, 1026-1031.

11 Jacobs, A.K. (2006). Components of evidencebased interventions for bullying and peer victimization.Issues in Clinical Child Psychology.SpringerLink.

12 Malekpour, M. (2007).Effect of attachment on nearly and later development.The British Journal of Developmental Disabilities. 53:2 (105), 81-95.

${ }^{13}$ Smith,P.R.(2004).Caringforpaidcaregivers:Linkingquality

ildcarewithimprovedworkingconditions.University of Cincinnati Law Review, 73,399-4

14 Schneider, B.H., Atkinson, L., \& Tardif, C. (2001). Child-parent attachment and children's peer relations: A.Quantitative Review. Developmental Psychology, 37(1), 86-100.

15 Appleyard, K., \& Berlin, L.J. (2007).Supporting healthy relationships between young children and their parents.Center for Child and Policy Duke University.

16 Ervika, E. (2005). Efektivitas pelatihan perilaku keibuan guna memperbaiki gangguan kelekatan. Thesis. Yogyakarta: Fakultas Psikologi UGM.

17 Walden, L.M., \& Beran, T.N. (2010).Attachment quality and bullying behavior in school-aged youth.Canadian Journal of School Psychology, 25(1) $5-18$

18 Pei, M. (2011).The Relation between parent-child attachment, child-rearing behaviors, and aggression in childhood and adolescence.Thesis. The Faculty of the Graduate School of Arts and Sciences,Brandeis University

19 Olweus, D. (2003). Bully/victim problems in school, Basic facts and an effective intervention programme. Dalam Einarsen, S., Hoel, H., Zapf, D., \& Cooper, C.L. (2003).Bullying and emotional abuse in the workplace, international perspectives in research and practice. New York: Taylor \& Francis.

20 Lines, D., op.cit (2008).

${ }^{21}$ Papalia D.E, Olds, S.W. Feldman, R.D. (2007). Human development tenth edition. New York: Mc Graw Hill.

22 Kazdin, A.E. (2000). Encyclopedia of Psychology.Volume 1.Washington, D.C.: Oxford University Press.

${ }^{23}$ Eisenberg, N. (2006). Empathy-related 
responding and prosocial behaviour.Empathy and Fairness.John Wiley \& Sons Ltd.

24 Ibid

25 Olweus, D., op.cit (2003)

26 Krahe, B. (2005). Perilaku agresif. Yogyakarta: Pustaka Pelajar.

27 Houbre, B., Tarquinio, C. \& Lanfranchi, J-B. (2010). Expression of self-concept and adjustment against repeated aggressions: the case of a longitudinal study on school bullying. European Journal of Psychology of Education, 25, 105-123.

28 Olweus, D., op.cit (2003)

29 Cunningham, N.J. (2007). Level of bonding to school and perception of the school environment by bullies, victims, and bully victims. The Journal of Early Adolescence, 27 (4), 457-478.

30 Baldry, A.C. \& Farrington, D.P. (2000). Bullies and delinquents: personal characteristics and parental styles. Journal of Community $\mathcal{E}$ Applied Social Psychology.10, 17-31.

31 Rigby, K. 2003. Consequences of bullying in schools.Canadian Journal of Psychiatry, 48(9), 583590.

32 Wahyuni, S. \& Nazifah, N., op.cit 2012.

33 Olweus, D., op.cit (2003).

34 Eisenberg, N., op.cit (2006).

35 Rigby, K., op.cit 2003

36 Sejiwa. (2008). Bullying: mengatasi kekerasan di sekolah dan lingkungan sekitar anak. Jakarta: Grasindo.

37 Appleyard, K., \& Berlin, L.J., op.cit (2007).

38 Malekpour, M., op.cit (2007).

39 Ibid

40 Appleyard, K., \& Berlin, L.J., op.cit (2007)

41 Malekpour, M., op.cit (2007).

42 Kerlinger,F.N., 1973. Foundation of behavioral Research. New York: Holt, Rinehart and Winnston Inc

43 Armsden, G \& Greenberg, M.T. (2009).Inventory of Parent and Peer Attachment (IPPA).College of Health and Human Development.

44 Sejiwa.op.cit (2008)

45 Walden, L.M., \& Beran, T.N.(2010).Attachment quality and bullying behavior in school-aged youth.Canadian Journal of School Psychology, 25(1) 5-18

46 Ibid

47 Schneider, B.H., Atkinson, L., \& Tardif, C., op.cit (2001)

48 Walden, L.M., \& Beran, T.N., op.cit (2010)

49 H. van IJzendoorn, Marinus. (1997). Attachment, Emergent Morality, and Aggression: Toward a Developmental Socioemotional Model of Antisocial Behaviour. International Journal of Behavioral Development, 21(4), 703-727.

50 Kõiv, K. (2012). Attachment Styles Among Bullies, Victims and Uninvolved Adolescents. Psychology Research, 2 (3), 160-165

51 O'Reilly, E. (2012). The impact of maternal employment on infant attachment and cognitive development.A literature review.MJSA, 1 (1), 29-32.
52 Huston, A.C. \& Aronson, S. R. (2005). Mothers' Time With Infant and Time in Employment as Predictors of Mother-Child Relationships and Children's Early Development. Child Development, 76 (2), $467-482^{53}$

54 Walden, L.M., \& Beran, T.N., op.cit (2010)

\section{DAFTAR PUSTAKA}

Ahmed, E. \& Braithwaite, V. (2004). Bullying and victimization: cause for concern for both families and schools. Social Psychology of Education 7, 35-54.

Armsden, G \& Greenberg, M.T. (2009). Inventory of Parent and Peer Attachment (IPPA).College of Health and Human Developmen.

Appleyard, K., \& Berlin, L.J. (2007). Supporting healthy relationships between young children and their parents. Center for Child and Policy Duke University.

Baldry, A.C. \& Farrington, D.P. (2000). Bullies and delinquents: personal characteristics and parental styles. Journal of Community \& Applied Social Psychology. 10, 17-31.

Centre for Parenting \& Research. (2006). The importance of attachment in the lives of foster children.NSW Department of Community Services. 
Cunningham, N.J. (2007). Level of bonding to school and perception of the school environment by bullies, victims, and bully victims. The Journal of Early Adolescence, 27 (4), 457-478.

Eisenberg, N. (2006). Empathy-related responding and prosocial behaviour. Empathy and Fairness. John Wiley \& Sons Ltd.

Ervika, E. (2005). Efektivitas pelatihan perilaku keibuan guna memperbaiki gangguan kelekatan. Thesis. Yogyakarta: Fakultas Psikologi UGM.

Glew, G.M., Fan, M-Y., Katon, W., Rivara, F.P., Kernic, M.A., (2005). Bullying, psychosocial adjustment, and academic performance in elementary school.Arch Pediatr Adolesc Med, 159, 1026-1031.

H. van IJzendoorn, Marinus. (1997). Attachment, Emergent Morality, and Aggression: Toward a Developmental Socioemotional Model of Antisocial Behaviour. International Journal of Behavioral Development, 21(4), 703-727.

Houbre, B., Tarquinio, C., Thuillier I. (2006). Bullying among students and its consequences on health.European Journal of
Psychology of Education, 21 (2), 183208.

Houbre, B., Tarquinio, C. \& Lanfranchi, J-B. (2010). Expression of selfconcept and adjustment against repeated aggressions: the case of a longitudinal study on school bullying. European Journal of Psychology of Education, 25, 105123.

Huston, A.C. \& Aronson, S. R. (2005). Mothers' Time With Infant and Time in Employment as Predictors of Mother-Child Relationships and Children's Early Development. Child Development, 76 (2), 467 - $482^{55}$

Jacobs, A.K. (2006). Components of evidence-based interventions for bullying and peer victimization. Issues in Clinical Child Psychology. SpringerLink.

Kazdin, A.E. (2000). Encyclopedia of Psychology.Volume 1.Washington, D.C.: Oxford University Press.

Kerlinger,F.N., 1973. Foundation of behavioral Research. New York: Holt, Rinehart and Winnston Inc

Kõiv, K. (2012). Attachment Styles Among Bullies, Victims and Uninvolved Adolescents. Psychology Research, 2(3), 160-165 
Konishi, C \& Hymel, S. (2009). Bullying and Stress in Early Adolescence: The Role of Coping and Social Support. Journal of Early Adolescence, 29 (3) 333-356.

Kowalski, R.M. \& Limber, S.P. (2013). Psychological, Physical, and Academic Correlates of Cyber bullying and Traditional Bullying. Journal of Adolescent Health 53 (2013) S13eS20.

Krahe, B. (2005). Perilaku agresif. Yogyakarta: Pustaka Pelajar.

Lai, S-L., Ye, R., \& Chang, K-P. (2008). Bullying in middle schools: an asian-pacific regional study. Asia Pacific Education Review, 9 (4), 503515.

Lines, D. (2008).The bullies, understanding bullies and bullying. London \& Philadelphia: Jessica Kingsley Publishers.

Malti, T., Perren, S. \& Buchmann, M. (2010).Children's Peer Victimization, Empathy, and Emotional Symptoms. Child Psychiatry Hum Dev, 41:98-113.

Malekpour, M. (2007).Effect of attachment on nearly and later development. The British Journal of Developmental Disabilities. 53:2 (105), 81-95.

Nansel, T. R., Overpeck, M., Pilla, R. S., Ruan, W. J., Simons-Morton, B., \& Scheidt, P. (2001). Bullying behaviors among U.S. youth: Prevalence and association with psychosocial adjustment. Journal of the American Medical Association, 285, 2094-2100.

Olweus, D. (2003). Bully/victim problems in school, Basic facts and an effective intervention programme. Dalam Einarsen, S., Hoel, H., Zapf, D., \& Cooper, C.L. (2003).Bullying and emotional abuse in the workplace, international perspectives in research and practice. New York: Taylor \& Francis.

O'Reilly, E. (2012). The impact of maternal employment on infant attachment and cognitive development.A literature review.MJSA, 1 (1), 29-32.

Papalia D.E, Olds, S.W. Feldman, R.D. (2007). Human development tenth edition. New York: Mc Graw Hill.

Pei, M. (2011).The Relation between parent-child attachment, childrearing behaviors, and aggression in childhood and adolescence. Thesis. The Faculty of 
Sri Wahyuni \& Yulita KA: Kecenderungan Anak Menjadi Pelaku dan Korban Bullying Ditinjau dari Kualitas Kelekatan dengan Ibu yang Bekerja

the Graduate School of Arts and Sciences, Brandeis University

Pontzer, D. (2010). A theoretical test of bullying behavior: parenting, personality, and the bully/victim relationship. Journal of Family Violance, 25, 259-273.

Rigby, K., \&Johnson, B. (2006). Expressed readiness of Australian school children to actas bystanders in support of children who are being bullied. Educational Psychology, 26, 425-440.

Rigby, K. 2003. Consequences of bullying in schools.Canadian Journal of Psychiatry, 48(9), 583590.

Sejiwa. (2008). Bullying: mengatasi kekerasan di sekolah dan lingkungan sekitar anak. Jakarta: Grasindo.

Schneider, B.H., Atkinson, L., \& Tardif, C. (2001). Child-parent attachment and children's peer relations: A. QuantitativeReview.Developmental Psychology, 37(1), 86-100.

Shechtman, Z. (2003). Cognitive and affective empathy in aggressive boys: Implications for counseling. International Journal for the Advancement of Counselling, 24, 211-222.
Smith, P.R. (2004). Caring for paid caregivers: Linking quality childcare with improved working conditions. University of Cincinnati Law Review, 73, 399-4

Totura, C., M., W., MacKinnon-Lewis, C., Gesten, E.L., Gadd, R., Divine, K.P., Dunham, S. \& Kamboukos, D. (2009).Bullying and Victimization Among Boys and Girls in Middle School: The Influence of Perceived Family and School Contexts. Journal of Early Adolescence, 29 (4), 571-609.

Uba, I., Yaacob, S.N., \& Juhari, R. (2009).The Relationship between Peer Relations and Depression among Adolescents in Selangor, Malaysia. European Journal of Social Sciences, 11 (1), 149-159.

Uba, I., Yaacob, S.N., Juhari, R., \&Talib, M.A. (2010).Effect of Self-Esteem on the Relationship between Depression and Bullying among Teenagers in Malaysia.Asian Social Science, 6 (12), 77-85.

Walden, L.M., \& Beran, T.N. (2010).Attachment quality and bullying behavior in school-aged youth.Canadian Journal of School Psychology, 25(1) 5-18

Wahyuni, S. \& Adiyanti, M.G. 
(2011).Correlation between perception toward parent's authoritarian parenting and ability to empathize with tendency of bullying behavior on teenagers. Jurnal Psikologi, 7 (2), 106-118.
Wahyuni,S.\&Nazifah, N.2012.Studicrosssectional perilaku bullying pada siswa SD, SMP, dan SMU di kota Pekanbaru Riau.Hasil Penelitian, dipresentasikan pada Temu Ilmiah IkatanPsikologiSosial, diPekanbaru pada tanggal 02 November 2012. 